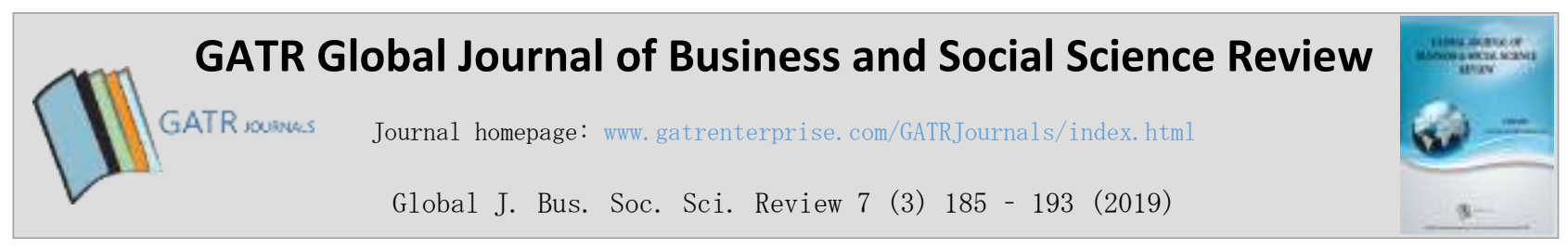

\title{
Social Responsibility of Higher Education Institutions: A New Insight into Stakeholders
}

\author{
Hedy D. Rumambi ${ }^{*}$, Revleen M. Kaparang ${ }^{2}$, Jerry S. Lintong ${ }^{3}$, Joseph N. Tangon ${ }^{4}$, Johanis \\ Ohoitimur $^{5}$ \\ 1,2,3,4 Manado State Polytechnic, North-Sulawesi, Indonesia \\ ${ }^{5}$ Higher Institute of Philosophy “Seminari Pineleng," Manado, North-Sulawesi, Indonesia
}

\begin{abstract}
Objective - Are stakeholders within the institution as actors, or are they also the goals of the institution's social responsibility? This study aims to provide new insight into the role of stakeholders in the implementation of social responsibility in Higher Education Institutions (HEI). Institutions have a certain level of social responsibility, which is inherent to its existence. To exist, an institution relies on the presence of stakeholders. Stakeholders are considered as the key to an institution's legitimacy. The relationship between an institution and its stakeholders can be described as a social contract.

Methodology/Technique - Using a qualitative approach, this study identifies the relevant stakeholders in HEI's and categorizes their roles and interests. The concept of HEI social dimension is used to analyze and interpret the data. The results indicate that HEI stakeholders consist of three levels, namely: primary (including management, lecturers, students, administrative staff, security officers, technicians, cleaning services, and the natural environment of the institution), secondary (including the local community, industries, alumni organizations, the government, accreditation agency, and the natural environment around the institution), and tertiary level (including society in general and nature).

Finding \& Novelty - The results suggest that the primary stakeholders become moral actors who carry out the institution's commitment to implement social responsibility. This finding implies that primary stakeholders become the executor and the goal of HEI social responsibility. Therefore, the institution's social responsibilities activities are aimed at the life and development of the institution itself. Social responsibility is carried out from the inside to the outside in a circular and continuous manner.
\end{abstract}

Type of Paper: Empirical.

Keywords: Social Responsibility; Higher Education Institution; Stakeholders; Social Dimension of HEI.

Reference to this paper should be made as follows: Rumambi, H. D; Kaparang, R. M; Lintong J. S; Tangon, J.N; O, Johanis. (2019). Social Responsibility of Higher Education Institutions: A New Insight into Stakeholders, Global J. Bus. Soc. Sci. Review 7 (3): 185 - 193. https://doi.org/10.35609/gjbssr.2019.7.3(3)

JEL Classification: M13, M14, M19.

\section{Introduction}

Social responsibility has always been an exciting topic of discussion in understanding an organization and its activities. To maintain its sustainability and to support good corporate governance, every organization is required to carry out certain social responsibilities.

\footnotetext{
* Paper Info: Revised: July 14, 2019

Accepted: September 21, 2019

* Corresponding author: Hedy D. Rumambi

E-mail: hedydr@yahoo.com

Affiliation: Accounting Department, Manado State Polytechnic, Indonesia.
} 
Social responsibility refers to an institution's commitment to respect the lives and development of its' stakeholders (Rumambi et. al., 2018). This defines responsibility as a moral attitude to respect the life of others. This concept flows from the social dimension of HEIs.

So far, social responsibility has been understood as a responsibility of the organization to engage various interested parties in their activities to fulfill their expectations. These interested parties can influence or be influenced by various policies, decisions, or operations of the organization (Post et. al., 2002). For this reason, social responsibility is inextricably linked with the roles and interests of stakeholders.

Some studies on higher education stakeholders emphasize the aspects of the expectation and the role of parties involved in institutional activities (Beerkens \& Udam, 2017; Stensaker \& Vabø, 2013; Diamond, 2008; Alves, Mainardes, \& Raposo, 2010). There is also other research relating to university stakeholder's management (Chapleo \& Sims, 2010). Consequently, the social responsibility of a HEI focuses on the institution's efforts to involve stakeholders in its activities, to fulfill their expectations, and to manage its stakeholders. This responsibility is a manifestation of social justice where the rights of all stakeholders must be considered and fulfilled. This kind of responsibility shows responsibility at the practical level.

In this study, we consider social responsibility from the conceptual level. These different perspectives, at both the practical and the conceptual levels, will provide a different understanding of the stakeholders of HEIs. By viewing social responsibility at the conceptual level, this study intends to provide new insight into stakeholders that are derived from the HEI's social dimension. This study contributes to HEI stakeholder theory and the concept of social responsibility. First, this study categorizes stakeholders into various levels. Second, the results of this study provide a new understanding of stakeholders and the implementation of social responsibility.

The paper is organized as follows. Section 2 is a literature review on an organization's legitimation and social contract, stakeholders, social dimension, and social responsibility. Section 3 describes the research approach, data collection, and data analysis to generate new insight into stakeholders. Section 4 presents the results of stakeholder identification and categorization as well as a discussion of their roles and involvements in the implementation of social responsibility. Section 5 concludes the paper.

\section{Literature Review}

A literature review is a description of the theory and research findings that provide a basis to develop a research framework on the role of stakeholders and their interests in the context of the social responsibility of HEIs.

\subsection{Legitimacy Theory}

Organizational existence needs obtains its legitimacy from the broader community. Legitimacy is a form of partisanship or acceptance and enables organizations to carry out their activities on an ongoing basis. By achieving community recognition, an organization can ensure that its operations are following the social values of the society in which it operates. Organizations need to conform to the norms that exist in society (O'Donovan, 2002; Deegan, 2004). The activities of an organization will be disrupted if the community does not recognize its legitimacy (Post et. al., 2002).

The organization management system must be in line with community expectations (Gray et. al., 1996). The implication, organization management are oriented towards interested parties of organizations, which are called stakeholders. The legitimacy of universities is related to the level and quality of the HEI's commitment to the community of stakeholders (Jongbloed et. al., 2007). This means that an organization will look for ways to engage stakeholders and be responsible for them. This demand will result in a new approach to governance and social responsibility from universities (Benneworth \& Arbo, 2006). 


\subsection{Stakeholder Theory}

Stakeholders are all parties who interact in organizational activities. Stakeholders consist of "any group or individual who can affect or is affected by the achievement of the objectives" (Freeman, 1984). Stakeholders also include agents (representatives), individuals and groups who can influence or become influenced when implementing an organization's objectives (Pesqueux \& Damak-Ayadi, 2012; Bourne \& Walker, 2005; Mainardes, Alves \& Raposo, 2012). These definitions have an expansive meaning. HEI stakeholders are grouped differently according to their roles and interests.

The groups are latent, expectant and definitive stakeholders (Mitchell et. al., 1997), internal and external (Burrows, 1999; Melewar \& Akel, 2005; Beerkens \& Udam, 2017), based on their participation (Reed, 2008), relational priorities and strategies (Mainardes, Alves \& Raposo, 2010), primary and secondary (Maric, 2013), overt and latent (Jongbloed, Enders \& Salerno, 2008; Garvare \& Johansson, 2010; Mainardes, Alves \& Raposo, 2013). The various categories of stakeholders means that HEIs need to synergize their roles and interests to create value for their stakeholders (Labanauskis \& Ginevičius, 2017).

\subsection{Social Contract Theory}

Social contracts occur because of the interaction between humans in society. In the context of social responsibility, the social contract is a license to operate (Kakabadse et. al., 2005). A license to operate is given by the community when the organization can behave reasonably and is responsible for its actions. Therefore, a social contract is an agreement from individuals or groups of individuals who live together in society. In practice, to fulfill its social commitment, HEIs need to balance the relationship between internal and external parties in implementing its governance. HEIs are expected to contribute to improving economic growth, job creation, and innovation (Maassen, 2014).

\subsection{Social Dimensions of HEIs}

HEIs have a social dimension, which flows from human sociality (Rumambi et. al., 2018). This indicates that, firstly, HEIs exist due to human presence. Existentially the presence of humans in the institution represents the legality of the institution. Secondly, HEIs are a humane community. This means that HEIs serves the joint-life of every individual in the institution; they work together to achieve common welfare. Thirdly, there are social interactions between HEIs and the community. They are interdependent. This interdependence makes each party's development and life influence each other. Fourthly, they have a responsibility to nature. Nature has an intrinsic value to itself, so it must be treated as a subject and not as a means of satisfying human needs. Responsibility towards nature means preserving the integrity of the environment (Rumambi, 2016). Fifthly, every activity of HEIs reflect their social responsibility. This is possible because social responsibility is inherent in the existence of HEIs.

\subsection{Social Responsibility of HEIs}

The social responsibility of HEIs is a responsibility inherent to the existence of the institution (Rumambi et. al., 2018). This social responsibility is intended for its stakeholders and flows from the social dimensions of the institution (Rumambi et. al., 2018). On the other hand, institutional social responsibility is understood as the principles of university social movement (Chen et. al., 2015) and is regarded as a part of the university's strategies (Vasilescu et. al., 2010; Gulavani et. al., 2016).

HEIs must meet the expectations of its stakeholders. In doing so, the institution will achieve a good reputation. This condition illustrates the institution's social responsibility to its stakeholders on a practical level. If it is understood in the social dimension of the institution, then social responsibility becomes a commitment of the institution to the welfare of its stakeholders (Rumambi et. al., 2018). 
Stakeholders cannot be seen as part of the company's strategy or part of the principle of social movements. Stakeholders are not only understood as those who have influence or are influenced by organizational activities (Pesqueux \& Damak-Ayadi, 2012; Bourne \& Walker, 2005; Mainardes, Alves \& Raposo, 2012; Mitchell et. al., 1997; Burrows, 1999; Melewar \& Akel, 2005; Beerkens \& Udam, 2017; Maric, 2013; Jongbloed, Enders \& Salerno, 2008; Garvare \& Johansson, 2010; Mainardes, Alves \& Raposo, 2013). Stakeholders must be understood more deeply as the executors and the goals of the institution's social responsibility.

\subsection{Research Framework}

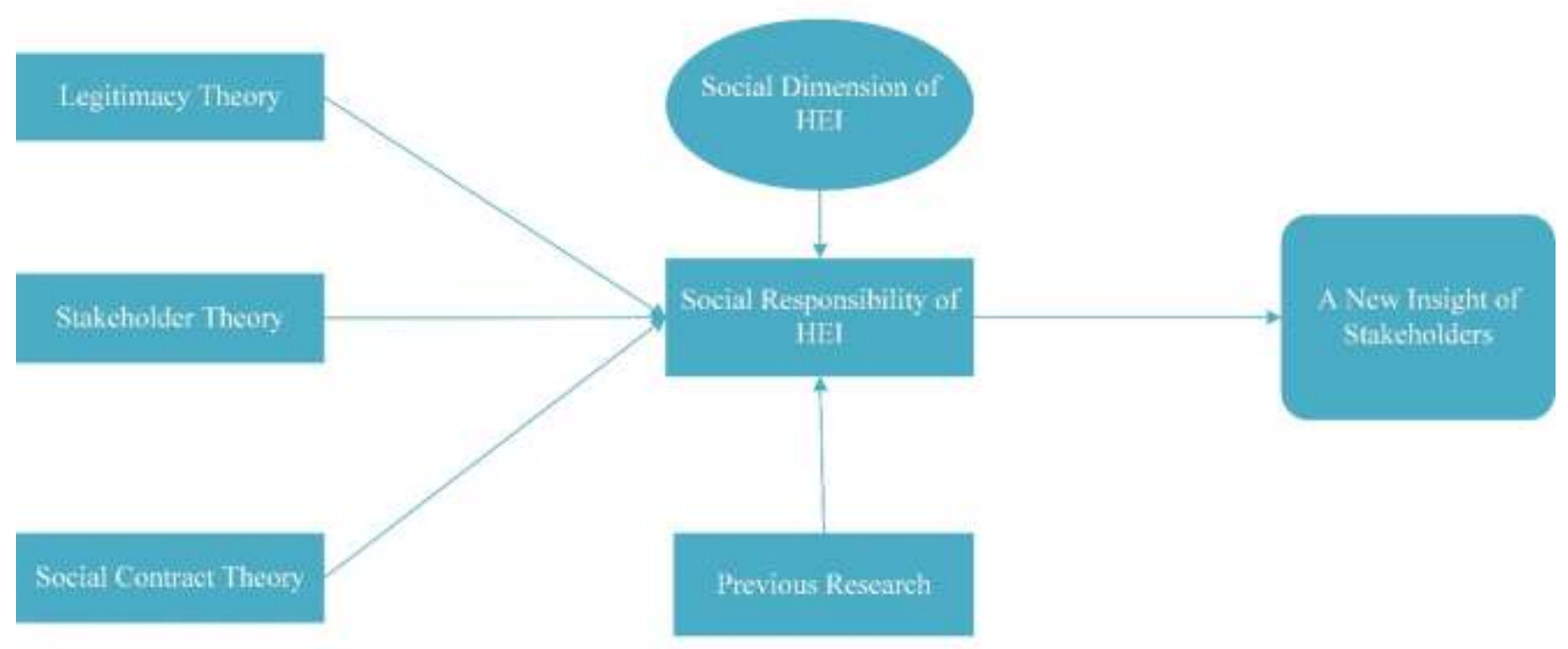

Figure 1. Research Framework

To understand the concept of social responsibility requires an understanding of legitimacy theory, stakeholder theory, and social contract theory. Every organization needs legitimacy from its stakeholders. The relationship between organizations and stakeholders is explained through the social contract theory and is reflected in organizational activities. Various studies describe the relationships and roles of stakeholders with the implementation of an organization's operations. This condition illustrates the meaning of stakeholders on a practical level. On the other hand, HEIs have a social dimension inherent in their existence. HEI social responsibility flows from its social aspect. In this context, the meaning of stakeholders will be different at the conceptual level.

\section{Research Methodology}

This study uses a qualitative approach with data analysis techniques adopted from Miles and Huberman (1994). Data was collected through interviews and literature studies. Several informants were interviewed to obtain data concerning the parties involvement in institutional activities and an examination of their roles and interests. Literature studies were conducted to highlight various research on stakeholders and other relevant theories. Data analysis and interpretation were conducted using the concept of HEI's social dimension to categorize its various stakeholders. 


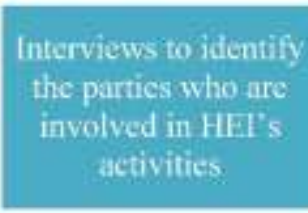

Literature studies

sbout stakeholders

and other relevant

theories
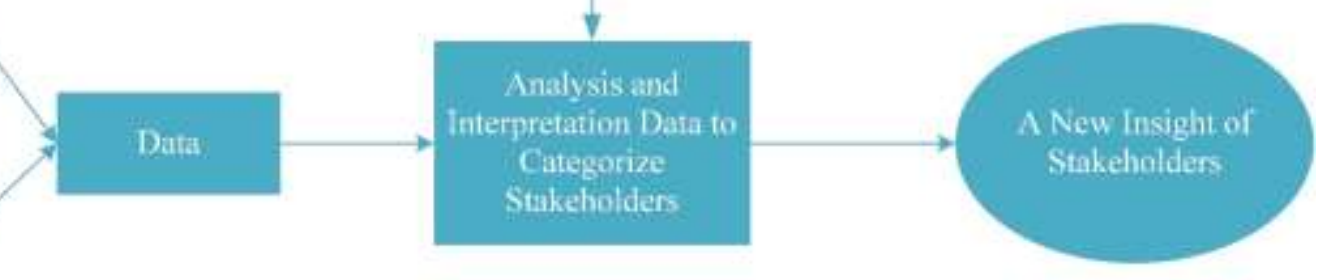

Figure 2. Research Methodology

\section{Results and Discussion}

A list of the various stakeholders that interact with the institution's activities can be seen in Table 1. Table 1 shows that each stakeholder has their respective roles and interests. Based on their roles and interests, stakeholders can be categorized into three levels.

Table 1. Multi-stakeholder category with their roles and interests

\begin{tabular}{|c|c|c|c|}
\hline Stakeholders & Category & Roles & Interests \\
\hline Management & Primary & Managing institution activities & Institution advancement \\
\hline Lecturer & Primary & $\begin{array}{l}\text { Carrying out teaching, research } \\
\text { and community service activities }\end{array}$ & Institution advancement \\
\hline Student & Primary & $\begin{array}{l}\text { Following the learning process } \\
\text { and other campus activities }\end{array}$ & Knowledge improvement \\
\hline $\begin{array}{l}\text { Administrative } \\
\text { staff }\end{array}$ & Primary & Doing the administrative work & $\begin{array}{l}\text { Institution progress and } \\
\text { advancement }\end{array}$ \\
\hline Parents & Primary & $\begin{array}{l}\text { Financing the student learning } \\
\text { process }\end{array}$ & Student Advancement \\
\hline Security officer & Primary & Assuring campus security & $\begin{array}{l}\text { Institution progress and } \\
\text { advancement }\end{array}$ \\
\hline Technician & Primary & Maintaining campus facilities & $\begin{array}{l}\text { Institution progress and } \\
\text { advancement }\end{array}$ \\
\hline Cleaning service & Primary & Maintaining campus cleanliness & $\begin{array}{l}\text { Institution progress and } \\
\text { advancement }\end{array}$ \\
\hline Local community & Secondary & $\begin{array}{l}\text { Supporting campus operation } \\
\text { (giving license to operate) }\end{array}$ & Social problem solving \\
\hline Industry & Secondary & $\begin{array}{l}\text { Absorbing university graduates as } \\
\text { labor }\end{array}$ & Quality human resources \\
\hline $\begin{array}{l}\text { Alumni } \\
\text { organization }\end{array}$ & Secondary & $\begin{array}{l}\text { Supporting and providing } \\
\text { contributions voluntarily to the }\end{array}$ & $\begin{array}{l}\text { Institution development in } \\
\text { a broader context }\end{array}$ \\
\hline
\end{tabular}

Global J. Bus. Soc. Sci. Review 7 (3) 185 -193 (2019) 
Hedy D. Rumambi, Revleen M. Kaparang, Jerry S. Lintong, Joseph N. Tangon, Johanis Ohoitimur

\begin{tabular}{|l|l|l|l|}
\hline & & institution & \\
\hline Government & Secondary & $\begin{array}{l}\text { Providing various sets of rules } \\
\text { related to institutional activities }\end{array}$ & $\begin{array}{l}\text { External monitoring and } \\
\text { evaluation representative }\end{array}$ \\
\hline $\begin{array}{l}\text { Accreditation } \\
\text { agency }\end{array}$ & Secondary & $\begin{array}{l}\text { Evaluating and determining the } \\
\text { level of accreditation }\end{array}$ & $\begin{array}{l}\text { External monitoring and } \\
\text { evaluation representative }\end{array}$ \\
\hline Society in general & Tertiary & $\begin{array}{l}\text { Contributing indirectly to } \\
\text { institution growth }\end{array}$ & Social problem solving \\
\hline Nature & $\begin{array}{l}\text { Primary } \\
\text { Secondary } \\
\text { Tertiary }\end{array}$ & $\begin{array}{l}\text { Supporting the implementation of } \\
\text { institution activities }\end{array}$ & $\begin{array}{l}\text { Environmental } \\
\text { conservation }\end{array}$ \\
\hline
\end{tabular}

Source: elaborated by authors

First, primary stakeholders refer to the ultimate component that must exist. The primary part of the HEI's existence is the presence of the executors who are operating the activities. They are the academic community and parents. The academic community refers to the groups of people involved in educational activities including management, lecturers, students, administrative staff, security officers, cleaning services, and technicians. Their presence enables the institution to operate (Rumambi et. al., 2018) and exist legally. Legality refers to the agreement or contract between each person in the institution to work together and achieve their vision. Their absence makes the institution disband. Further, nature in the campus environment is one of the primary stakeholders. There are mutual relationships between an institution and its environment. When the environment is disturbed, this will cause discomfort. This relationship illustrates the intrinsic value possessed by nature meaning that the integrity of nature must be maintained (Rumambi, 2016).

Secondary stakeholders refer to supplementary or supporting components that complement the primary part. Secondary stakeholders include the local community, industry, alumni organizations, accreditation agencies, and the government. The social dimension of the institution not only describes the existence of social interactions among individuals within the institution. Social interaction becomes concrete in its relationship with people outside of the institution because there are interdependencies between the institutions and society (Rumambi et. al., 2018). This is evident in the roles and interests of the secondary stakeholders (refer to Table 1). They are involved externally in institutional activities.

To achieve its vision and mission, an institution needs support from secondary stakeholders. To find this support, HEIs must operate in accordance with the social norms and values that exist in society (O' Donovan, 2002; Deegan, 2004) and fulfill the expectations of their stakeholders (Gray et. al., 1996). This support strengthens the institution's legitimacy so that its existence is accepted and recognized by the community (Post et. al., 2002). This is why the institution needs to engage stakeholders and be responsible for them (Jongbloed et. al., 2007). The institution plays an essential role in the lives of the surrounding community. Through the activities of teaching, research, and community services, the institution can help solve various social problems. This second level also includes the natural environment around the campus. The environmental conditions also influence the institution's sustainability.

Third, tertiary stakeholders include society in general and nature. These components are affected indirectly by the activities of the institution. Even though they have an indirect relationship with HEIs, the existence, life, and development of the institution cannot be separated from their support. As illustrated in Table 1, both nature and society in general have different roles and interests in the life of the institution.

Social responsibility in the sense of the institution's commitment provides new insight into the role and responsibilities of stakeholders. Research by Maric (2013) analyzes stakeholders of the primary and secondary categories based on the concept of knowledge management. Maric categorizes primary groups such as government, the Ministry of Science and Education, national agencies, and society. The secondary groups include students, employees, competitions, and other faculties. Maric's research differs from this study. The stakeholder concept in this study was built from the social dimension of HEIs. Stakeholders are

Global J. Bus. Soc. Sci. Review 7 (3) 185 -193 (2019) 
categorized into three groups, and primary stakeholders are the starting point for the implementation of social responsibility.

The existence of an institution must draw its legitimacy from the community. Primary stakeholders are the closest community to the institution so that, in essence, the legitimacy of the institution is determined by the primary stakeholders. As the activities of the institution progress, legitimacy is also determined by the secondary and tertiary stakeholders. The relationship between the institution and its primary, secondary, and tertiary stakeholders illustrates the implicit existence of a social contract between the institution and its stakeholders. Therefore, the institution must behave fairly and is responsible for its actions (Kakabadse et. al., 2005). The life and development of an institution is influenced by the involvement of its stakeholders and vice versa. The social interaction that occurs between them gives rise to a license to operate for use by the institution.

If the relationship between an institution and its stakeholders is understood in the context of social responsibility, the deepest social responsibility reflects the institution's commitment to the welfare and lives of the primary stakeholders. HEIs therefore need to synergize the roles and interests of their stakeholders (Labanauskis \& Ginevičius, 2017). This process and the institution's commitment to its primary stakeholders become concrete in the implementation of its' activities to foster a sense of belonging to the primary stakeholders. Therefore, the commitment to respect the lives and welfare of an institution's stakeholders is a moral value that underlies the involvement of primary stakeholders to carry out institutional activities responsibly. Thus, the implementation of social responsibility through an institution's activities begins with the primary stakeholders and moves towards the secondary and tertiary stakeholders.

\section{Conclusion}

The identification and categorization of various stakeholders from the perspective of the social dimension of HEIs provides a novel view on institutional stakeholders. Primary stakeholders become the moral actors responsible for the execution of the goals of the institution. The commitment of the institution is intended to respect the life and development of the institution itself and society in general through the implementation of HEI social responsibility. HEI social responsibility is implemented in the first level (primary stakeholders) and flows through to the second level (secondary stakeholders) and ends with the third level (tertiary stakeholders).

This implementation process can be analogous to the form of a spiral. The deepest point (first level) is the starting point. This starting point represents the responsibility that grows from the sense of belonging of the primary stakeholders. This sense of belonging will encourage primary stakeholders to implement the institution's social responsibility activities. The implementation process will be carried out in a circular and continuous manner from inside the institution to the secondary and tertiary stakeholders.

This research provides new insight into the role of stakeholders within social responsibility by using the social dimension of HEIs. Future research may adopt a different view and a broader scope to enrich the findings of the study. New research can also be conducted to build a model for the implementation of social responsibility based on the roles and interests of the primary, secondary, and tertiary stakeholders. With the different roles and interests of various stakeholders, further research is needed in the area of stakeholder management. HEIs need to balance the relationship between the various stakeholders under its governance (Maassen, 2014).

\section{Acknowledgments}

We would like to deeply thank the Directorate of Research and Community Service, Ministry of Research, Technology and Higher Education of the Republic of Indonesia who have provided funding for our research. Sincere thanks are also due to the center of research and community service of Manado State Polytechnic that has facilitated this research. 


\section{References}

Alves, H., Mainardes, E. W., \& Raposo, M. (2010). A relationship approach to higher education institution stakeholder management. Tertiary Education and Management, 16(3), 159-181. https://doi.org/10.1080/13583883.2010.497314

Beerkens, M., \& Udam, M. (2017). Stakeholders in higher education quality assurance: Richness in diversity? Higher Education Policy, 30(3), 341-359. https://doi.org/10.1057/s41307-016-0032-6

Arbo, P., \& Benneworth, P. (2007). Understanding the regional contribution of higher education institutions. https://doi.org/10.1787/161208155312

Bourne, L., \& Walker, D. H. (2005). Visualising and mapping stakeholder influence. Management decision, 43(5), 649660. https://doi.org/10.1108/00251740510597680

Burrows, J. (1999). Going beyond labels: A framework for profiling institutional stakeholders. Contemporary Education, $\quad 70(4), \quad 5 . \quad$ https://search.proquest.com/openview/92a1bb2e62f2059cc33d4fb42023839b/1?pqorigsite $=$ gscholar $\& \mathrm{cbl}=41688$

Chapleo, C., \& Simms, C. (2010). Stakeholder analysis in higher education: A case study of the University of Portsmouth. Perspectives, 14(1), 12-20. https://doi.org/10.1080/13603100903458034

Chen, S. H., Nasongkhla, J., \& Donaldson, J. A. (2015). University Social Responsibility (USR): Identifying an Ethical Foundation within Higher Education Institutions. Turkish Online Journal of Educational Technology-TOJET, 14(4), 165-172. https://eric.ed.gov/?id=EJ1077652

Deegan C (2004) Financial accounting theory. McGraw-Hill, Australia

Diamond, R. M. (1998). Designing and Assessing Courses and Curricula: A Practical Guide. The Jossey-Bass Higher and Adult Education Series. Jossey-Bass, Inc., Publishers, 350 Sansome St., San Francisco, CA 94104-1310; toll-free. https://eric.ed.gov/?id=ED417665

Freeman R (1984) The politics of stakeholder's theory: some future directions. Business Ethics Quarterly 4(4):409-422. https://doi.org/10.2307/3857340

Garvare R, Johansson P (2010) Management for sustainability - A stakeholder theory. Total Quality Management \& Business Excellence 21(7):737-744. https://doi.org/10.1080/14783363.2010.483095

Gray, R., Owen, D., \& Adams, C. (1996). Accounting \& accountability: changes and challenges in corporate social and environmental reporting. Prentice Hall. http://eprints.gla.ac.uk/95486/

Gulavani S, Nayak N, Nayak M (2016) CSR in higher education. IOSR Journal of Business and Management 18(10): 37-39. www.iosjournals.org $>$ Vol18-issue10>Version-7

Jongbloed, B. W., Enders, J., \& Salerno, C. S. (2007). Higher education and its communities: Interconnections and interdependencies. https://research.utwente.nl/en/publications/higher-education-and-its-communities-interconnectionsand-interde

Jongbloed, B., Enders, J., \& Salerno, C. (2008). Higher education and its communities: Interconnections, interdependencies and a research agenda. Higher education, 56(3), 303-324. http://dx.doi.org/10.1007/s10734-0089128-2

Kakabadse, N. K., Rozuel, C., \& Lee-Davies, L. (2005). Corporate social responsibility and stakeholder approach: a conceptual review. International Journal of Business Governance and Ethics, 1(4), 277-302.

https://doi.org/10.1504/IJBGE.2005.006733

Labanauskis, R., \& Ginevičius, R. (2017). Role of stakeholders leading to development of higher education services. Engineering Management in Production and Services, 9(3), 63-75. https://doi.org/10.1515/emj-2017-0026

Maassen, P. (2014). A new social contract for higher education? In Higher education in societies (pp. 33-50). Brill Sense. https://doi.org/10.1007/9789462097469_005

Mainardes, E. W., Alves, H., \& Raposo, M. (2010). An exploratory research on the stakeholders of a university. Journal of Management and Strategy, 1(1), 76. https://doi.org/10.5430/jms.v1n1p76

Wagner Mainardes, E., Alves, H., \& Raposo, M. (2012). A model for stakeholder classification and stakeholder relationships. Management decision, 50(10), 1861-1879. https://doi.org/10.1108/00251741211279648

Mainardes, E., Alves, H., \& Raposo, M. (2013). Identifying stakeholders in a Portuguese university: a case study: The identity of other stakeholders in a Portuguese university. Ministerio de Educación. https://doi.org/10.4438/1988-592XRE-2012-362-167

Marić, I. (2013). Stakeholder analisys of higher education institutions. Interdisciplinary Description of Complex Systems: INDECS, 11(2), 217-226. https://doi.org/10.7906/indecs.11.2.4 
Melewar, T. C., \& Akel, S. (2005). The role of corporate identity in the higher education sector: A case study. Corporate Communications: An International Journal, 10(1), 41-57. https://doi.org/10.1108/13563280510578196 Miles, MB, Huberman AM (1994) Qualitative Data Analysis. Sage Publishers, London

Mitchell, R. K., Agle, B. R., \& Wood, D. J. (1997). Toward a theory of stakeholder identification and salience: Defining the principle of who and what really counts. Academy of management review, 22(4), 853-886. https://doi.org/10.2307/259247

O'Donovan, G. (2002). Environmental disclosures in the annual report: Extending the applicability and predictive power of legitimacy theory. Accounting, Auditing \& Accountability Journal, 15(3), 344-371.

https://doi.org/10.1108/09513570210435870

Pesqueux, Y., \& Damak-Ayadi, S. (2005). Stakeholder theory in perspective. Corporate Governance: The international journal of business in society, 5(2), 5-21. https://doi.org/10.1108/14720700510562622

Post, J. E., Lawrence, A. T., Weber, J., \& SJ, J. W. (2002). Business and society: Corporate strategy, public policy, ethics. McGraw-Hill/Irwin. https://www.amazon.com/Business-Society-Corporate-Strategy-Public/dp/0071101020

Reed, M. S. (2008). Stakeholder participation for environmental management: a literature review. Biological conservation, 141(10), 2417-2431. https://doi.org/10.1016/j.biocon.2008.07.014

Rumambi, H. D. (2016). The Implementation of Corporate Social Responsibility (CSR) in The Light of Common Good. Research Journal of Finance and Accounting, $100-107$. https://www.iiste.org/Journals/index.php/RJFA/article/view/33675

Rumambi HD, Kaparang RM, Lintong JS, Tangon JN (2018) What is corporate social responsibility (CSR) in higher education institution? International Journal of Management and Applied Science, 4(10):9-12. IJMAS-IRAJ-DOI-14086. http://ijmas.iraj.in//paper_detail.php?paper_id=14086\&

Stensaker, B., \& Vabø, A. (2013). Re-inventing shared governance: Implications for organisational culture and institutional leadership. Higher Education Quarterly, 67(3), 256-274. https://doi.org/10.1111/hequ.12019

Vasilescu, R., Barna, C., Epure, M., \& Baicu, C. (2010). Developing university social responsibility: A model for the challenges of the new civil society. Procedia-Social and Behavioral Sciences, 2(2), 4177-4182.

https://doi.org/10.1016/j.sbspro.2010.03.660 